\title{
Marsupialisation: a treatment modality of a dentigerous cyst
}

\author{
Satnam Singh, ${ }^{1}$ Kamaljit Kaur, ${ }^{2}$ Gulsheen Kaur Kochhar, ${ }^{2}$ Akshat Gupta ${ }^{1}$
}

${ }^{1}$ Department of Oral and Maxillofacial Surgery, Post Graduate Institute of Medical Education and Research, Chandigarh, India ${ }^{2}$ Department of Pedodontics and Preventive Dentistry, Swami Devi Dyal Hospital \& Dental College, Panchkula, Haryana, India

\section{Correspondence to} Dr Gulsheen Kaur Kochhar, gulsheenuppal@gmail.com

Accepted 4 August 2014

\section{DESCRIPTION}

Dentigerous cysts or follicular cysts may be developmental or inflammatory in origin. Treatment of inflammatory cysts should be performed in a conservative manner without causing undue damage to the succedaneous tooth. ${ }^{1}$

This is a case report of a large inflammatory dentigerous cyst that was managed conservatively by marsupialisation.

A 13-year-old boy presented with painless swelling in the area of the left lower back tooth for 1 month. On extraoral examination, a slight buccal bulge that was hard on palpation was seen. Intraoral examination revealed a grossly decayed 75 . An orthopantomogram X-ray was advised, which revealed a well-defined unilocular radiolucency in relation to 75 (figure 1). The radiolucency also involved unerupted 35 (figure 2). A provisional diagnosis of inflammatory dentigerous cyst was made. Marsupialisation of the cyst was planned to prevent any undue damage to the succedaneous tooth. Routine blood investigations were advised, which showed normal values.

75 was extracted under local anaesthesia. A thick, straw coloured fluid was drained during the procedure. Tissue from the cavity was sent for histological

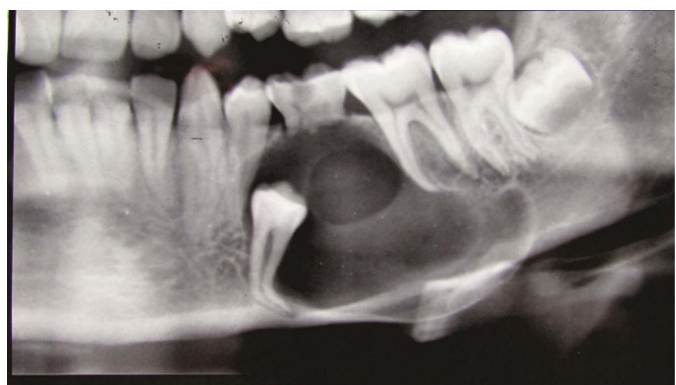

Figure 1 Orthopantomogram showing unilocular radiolucency in 75 .

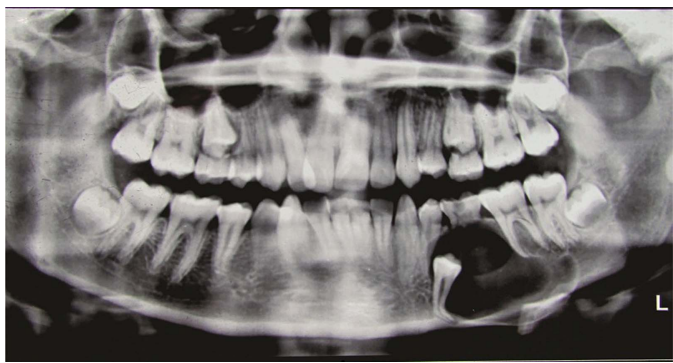

To cite: Singh S, Kaur K Kochhar GK, et al. BMJ Case Rep Published online: [please include Day Month Year] doi:10.1136/bcr-2014205150
CrossMark

Figure 2 Radiolucency involving 35.

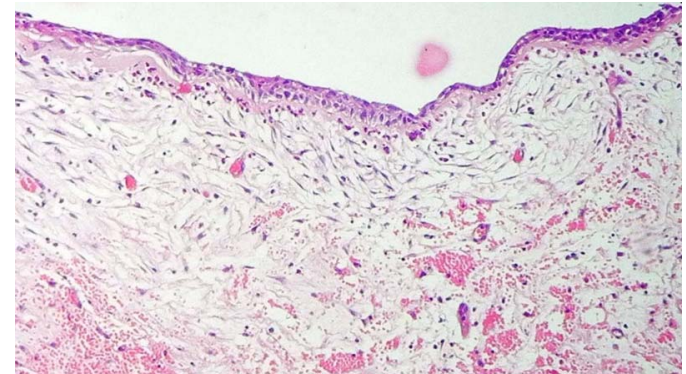

Figure 3 Histological examination of lesion confirming dentigerous cyst.

examination, which confirmed an inflammatory dentigerous cyst (figure 3). Buccal and lingual cortical plates were compressed and left open for drainage. The patient was prescribed with antibiotics and analgaesics and discharged after giving instructions.

Follow-up was carried out after 1 week, 1 month (figure 4), 3 months (figure 5), 6 months (figure 6) and 9 months (figure 7).

After 9 months, 35 erupted in the oral cavity with complete bone healing (figure 8 ). The patient was advised orthodontic consultation for maligned teeth.

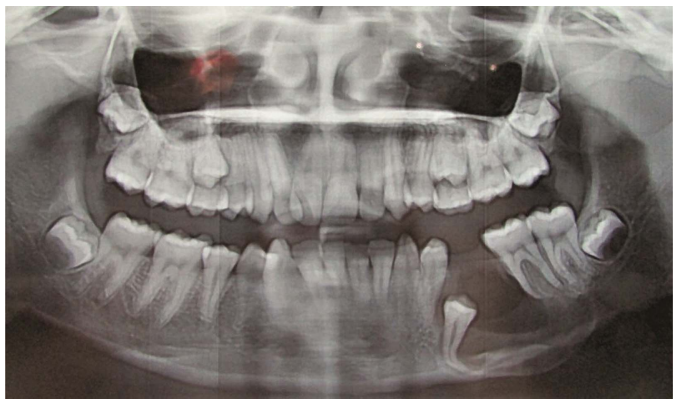

Figure 4 Follow-up after 1 month.

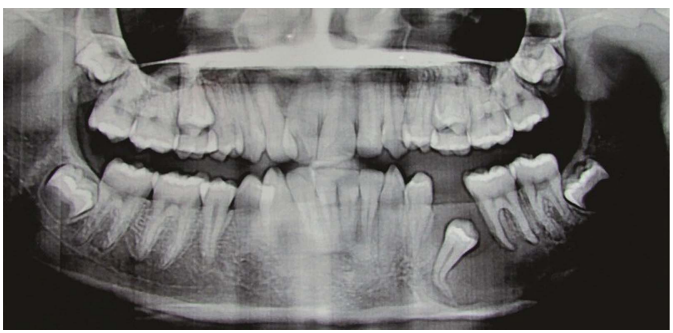

Figure 5 Follow-up after 3 months. 


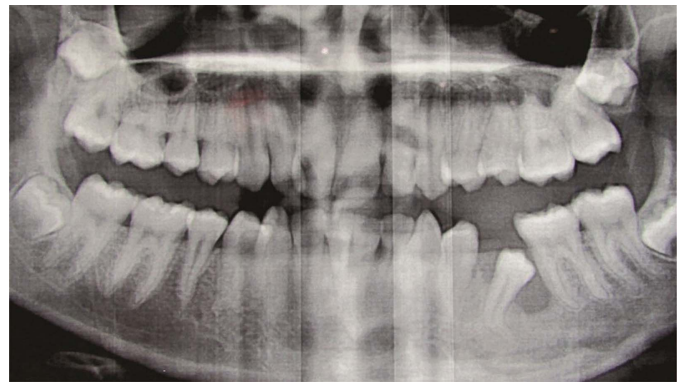

Figure 6 Follow-up after 6 months.

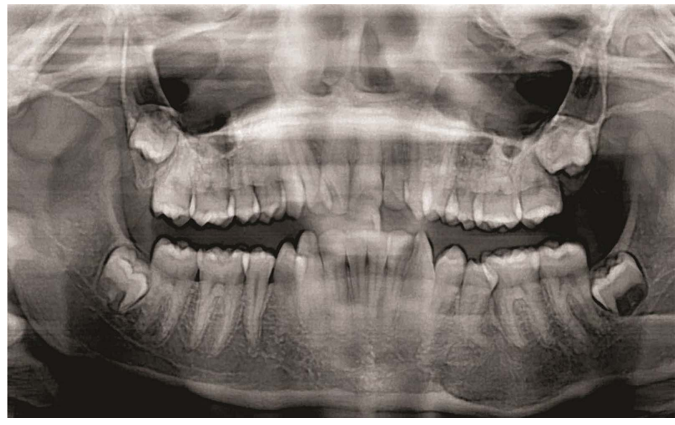

Figure 7 Follow-up after 9 months. An orthopantomogram showing complete eruption of 35 .

\section{Competing interests None.}

Patient consent Obtained.

Provenance and peer review Not commissioned; externally peer reviewed.

\section{REFERENCES}

1 Koca H, Esin A, Aycan K. Outcome of dentigerous cyst treated with marsupialization. J Clin Pediatr Dent 2009;34:165-8.

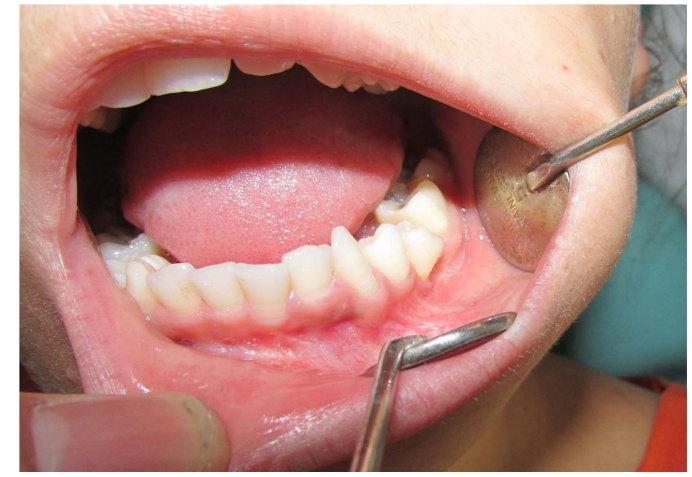

Figure 8 Clinically erupted 35.

\section{Learning points}

- Dentigerous cysts are the most common of all developmental cysts of odontogenic origin and account for $20-24 \%$ of all jaw cysts. ${ }^{2}$ They are more frequently seen in males and more common in the mandibles.

- Inflammatory dentigerous cysts occur in immature permanent teeth due to the spread of inflammation from overlying non-vital primary teeth.

- Marsupialisation of an odontogenic cyst has an advantage over enucleation as cystic lining has an inherent tendency to contract (due to myofibroblast) after release of cystic content and allow endosteal bone formation to take place. ${ }^{3}$

2 Kirtaniya BC, Sachdev V, Singla A, et al. Marsupialization: a conservative approach for treating dentigerous cyst in children in the mixed dentition. $J$ Indian Soc Pedod Prev Dent 2010;28:203-8.

3 Soliman MM, Dayem Hassan HA, Elgazaerly $H$, et al. Marsupialization as a treatment modality of large jaw cysts. World App/ Sci J 2013;21:1752-9.

Copyright 2014 BMJ Publishing Group. All rights reserved. For permission to reuse any of this content visit

http://group.bmj.com/group/rights-licensing/permissions.

BMJ Case Report Fellows may re-use this article for personal use and teaching without any further permission.

Become a Fellow of BMJ Case Reports today and you can:

- Submit as many cases as you like

- Enjoy fast sympathetic peer review and rapid publication of accepted articles

- Access all the published articles

- Re-use any of the published material for personal use and teaching without further permission

For information on Institutional Fellowships contact consortiasales@bmjgroup.com

Visit casereports.bmj.com for more articles like this and to become a Fellow 